\title{
In Defence of the Migrant Workers Convention: Standard Setting for Contemporary Migration
}

\author{
Bernard Ryan ${ }^{1}$
}

\section{Introduction}

The International Convention on the Protection of the Rights of All Migrant Workers and Members of Their Families ('the Migrant Workers Convention') has had a difficult history. The adoption of a treaty on the subject of migrant workers was formally proposed by a General Assembly resolution of 17 December $1979 .{ }^{2}$ As a result of differences of opinion between states of origin and destination, however, the final text was not endorsed by the General Assembly until 18 December $1990 .^{3}$ There was then a further lengthy period until the Convention came into force on 1 July 2003, once the requisite 20 ratifications had been obtained. Since then, ratification has proceeded slowly, with a total of 44 states having ratified by early 2011.

In contrast to the doubts that have often been expressed as to the value of the Migrant Workers Convention, this chapter will argue for its potential as a source of standards concerning international migration. Section 1 will consider the text of the Convention, and will show that it is a coherent instrument for the protection of migrants as a category. Section 2 will then consider the Convention in practice, arguing that its strength lies in a combination of two factors: the migration experiences of the states that have ratified it, and the interpretative work of the Committee on Migrant Workers since it was established on 1 January 2004. That combination enables the Convention to be an effective and authoritative source of standards on the treatment of migrants.

\footnotetext{
1 Professor of Law, University of Kent. I am grateful to Ryszard Cholewinski, Virginia Mantouvalou and Eki Yemisi Omorogbe for their comments on the paper in draft.

2 UNGA Resolution 34/172, 17 December 1979.

3 UNGA Resolution 45/158, 18 December 1990.
} 


\section{The Migrant Workers Convention}

The origins of the Migrant Workers Convention lie in the postwar period of high demand for migrant labour in the developed countries of Europe and North America. At the international level, standards on international migration were initially developed within the International Labour Organization. The Migration for Employment Convention (Revised), 1949 (No. 97) provided for the equal treatment of lawfully resident migrant workers. ${ }^{4}$ More significantly, the Migrant Workers (Supplementary Provisions) Convention 1975 (No. 143) focused on irregular migration and employment. It required contracting states to take action against 'the organisers of illicit or clandestine movements of migrants for employment', and against 'those who employ workers who have immigrated in illegal conditions' ${ }^{\prime}{ }^{5}$ That approach to irregular migration and employment was followed by calls from states of origin - led by Mexico and Morocco - for a new treaty that was more concerned with the interests of their nationals. ${ }^{6}$ Because the ILO structures gave a greater say to 'industrialized' countries, the preference of states of origin was for such an instrument to be adopted through the United Nations General Assembly.

The debate over the Convention was initially quite polarized. ${ }^{7}$ Seventeen developed Western countries had indicated their scepticism about the proposal for a Convention by abstaining on the General Assembly resolution setting up the working group in $1979 .{ }^{8}$ When an initial draft Convention was presented in May 1981, with the support of five states of emigration, the most developed countries rejected it as 'a blank check for continued illegal migration'. .9 The intervention of a group of seven Southern European and Nordic states proved decisive, and the eventual text of the Convention reflected their broadly socially democratic approach to migration. ${ }^{10}$ On the one hand, Part III of the Convention extended many human and labour rights to migrant workers and their families, irrespective of immigration status. On the other hand, irregular migrant and employment was discouraged, in two ways: Part

$4 \quad$ ILO Convention 97, Article 6.

5 ILO Convention 143, Article 3(b).

6 On the history of the Convention, see Roger Böhning, 'The ILO and the New UN Convention on Migrant Workers: The Past and Future' (1991) 25 International Migration Review 698-709, and Graziano Battistella, 'Migration and Human Rights: The Uneasy but Essential Relationship' in Paul de Guchteneire, Antoine Pécoud and Ryszard Cholewinski (eds), Migration and Human Rights: The United Nations Convention on Migrant Workers' Rights (Cambridge University Press, Cambridge, 2009) 47-69.

7 On the drafting of the Convention, see Juhani Lönnroth, 'The International Convention on the Rights of All Migrant Workers and Members of Their Families in the Context of International Migration Policies: An Analysis of Ten Years of Negotiation' (1991) 25 International Migration Review $710-36$.

8 For the list, see Battistella, 'Migration and Human Rights', 54 . This group of states included 12 West European states (Austria, Belgium, Denmark, Finland, France, West Germany, Iceland, Luxembourg, the Netherlands, Norway, Sweden and the United Kingdom) and five other highly developed states (Australia, Canada, Israel, New Zealand and the United States). Burma and Guatemala also abstained.

9 Böhning, 'ILO and the New UN Convention on Migrant Workers', 701. The 1981 draft was initially endorsed by Algeria, Mexico, Pakistan, Turkey and Yugoslavia, and later supported by Barbados and Egypt: Battistella, 'Migration and Human Rights', 55.

10 These were Finland, Greece, Italy, Norway, Portugal, Spain and Sweden. 


\section{O) Copyrighted Material}

IV of the Convention conferred certain rights solely on workers in a lawful position, while Part VI of the Convention - which is concerned with 'sound, equitable, humane and lawful conditions' in international migration - provided for measures to prevent irregular migration and employment.

These features of the Convention have in turn given rise to two frequent criticisms since it was negotiated: that it overlaps unnecessarily with other international instruments, and that it gives insufficient protection to irregular migrants. The rest of this section will address these criticisms, through a review of the content of the Convention.

\section{Overlap}

Criticism of the Migrant Workers Convention for overlapping unnecessarily with other instruments began even before the text of the Convention had been formally adopted. Writing in 1988, Roger Böhning observed, with reference to the International Covenant on Civil and Political Rights (ICCPR) and the International Covenant on Economic, Social and Cultural Rights (ICESCR), that Part III of the Convention 'almost entirely repeats textually the provisions of one Covenant or the other, which demonstrates that there was no need for a new convention in this respect.' ${ }^{\prime 1}$ That line of criticism was developed in particular by James Nafziger and Barry Bartel, who argued in an article in 1991 that overlaps would 'obfuscate or obscure the enforcement of both the Convention and corresponding human rights instruments that are designed to protect everyone, including migrant workers. ${ }^{\prime 2}$ More recently, Vincent Chetail has remarked that, 'from a purely legal perspective, the added value of the ICMW is relatively limited given that most of its provisions simply restate - and sometimes specify - basic human rights which are already enshrined in other general instruments. ${ }^{13}$

This line of criticism will be addressed here through an examination of the Convention's provisions on personal scope (Article 3) and non-discrimination (Article 7), and of the rights it recognizes for all migrant workers and their families (Part III of the Convention). It will be argued that overlaps of content are explicable in terms of the Convention's underlying objective of protecting migrants. Because of that objective, the rights-conferring provisions of the Convention either go beyond other instruments in significant ways, or else merit inclusion in the Convention because of their distinct relevance for migrants.

\section{Personal scope}

Article 2 of the Convention, which sets out its personal scope, gives a first example of its content going beyond other instruments. ${ }^{14}$ It defines the term 'migrant worker' to mean 'a person who

11 Roger Böhning, 'The Protection of Migrant Workers and International Labour Standards' (1988) 26(2) International Migration Review 133-46, at 143.

12 James Nafziger and Barry Bartel, 'The Migration Workers Convention: Its Place in Human Rights Law' (1991) 25 International Migration Review 771-99, at 787.

13 Vincent Chetail, 'Review of Migration and Human Rights: The United Nations Convention on Migrant Workers' (2010) 22 International Journal of Refugee Law 677-82, at 679.

${ }_{14}$ For an earlier discussion, see Ryszard Cholewinski, Migrant Workers in International Human Rights Law: Their Protection in Countries of Employment (Oxford University Press, Oxford, 1997) 149-52. 
is to be engaged, is engaged or has been engaged in a remunerated activity in a State of which he or she is not a national. ${ }^{\prime 15}$ This definition may be contrasted in particular with the two ILO Conventions in the field. ILO Convention 97 applies to a 'migrant for employment', defined as 'a person who migrates or who has migrated from one country to another with a view to being employed otherwise than on his own account. ${ }^{16}$ The same formulation appears in ILO Convention 143, in order to define the category of 'migrant workers'. ${ }^{17}$

The definitions in the Migrant Workers Convention and the ILO Conventions have in common that they potentially cover workers whose stay and/or economic activity is irregular. In other respects, however, the Migrant Workers Convention's personal scope is far broader. One reason is that the Convention definition includes all foreign nationals who engage in remunerated activity, without it being necessary that they have migrated for employment. It therefore includes foreign national workers lawfully in a contracting state for other reasons, such as a family relationship, or who have never migrated, because they were born there. A second difference is that the Convention's focus on 'remunerated activity', rather than employment, means that both employees and the self-employed are included. ${ }^{18}$ The inclusion of self-employment is of particular relevance to irregular migrants, who often work outside formal employment relationships. A third difference is the reference in the Convention to past economic activity, which ensures that the Convention applies to those who have previously engaged in economic activity in the state in question.

The broad personal scope of the Convention, going beyond current workers, was one of the criticisms of it made by Nafziger and Bartel in their 1991 article. ${ }^{19}$ Yet it can equally be argued that the breadth of Article 2 is one of its strengths, as central to the Convention's potential as an instrument concerning migrants in general. We will see in this section how that potential has been reflected in Part III of the Convention, and in section 2, how it has been carried forward in the work of the Committee on Migrant Workers.

\section{Non-discrimination clause}

The Convention's non-discrimination guarantee is a second example of a provision that goes further than other instruments. Under Article 7, contracting states are obliged

to respect and to ensure ... the rights provided for in the present Convention without distinction of any kind such as to sex, race, colour, language, religion or conviction, political or other opinion, national, ethnic or social origin,

15 A number of exceptions are set out in Article 3: persons sent by international organizations and foreign states; investors; refugees and stateless persons; students and trainees; and seafarers and workers in offshore installations who are not authorized to reside and work in the state in question.

16 ILO Convention 97, Article 11(1).

17 ILO Convention 143, Article 11(1), which refers solely to the rights applicable to workers in a lawful position set out in its Part II. The provisions concerning irregular migration in Part I of that Convention are not governed by an express statement of personal scope.

18 This is confirmed by Articles 2(2)(h) and 63, which specifically concern the self-employed.

19 Nafziger and Bartel, 'Migration Workers Convention', 786. 


\section{(C) Copyrighted Material}

nationality, age, economic position, property, marital status, birth or other status.

The breadth of this formulation is apparent from a comparison with the equivalent provisions in Article 2(1) ICCPR and Article 2(2) ICESCR.${ }^{20}$ Under each of those, contracting states undertake 'to respect and to ensure ... the rights recognized in the present Covenant, without distinction of any kind, such as race, colour, sex, language, religion, political or other opinion, national or social origin, property, birth or other status.' By comparison, Article 7 adds non-religious convictions, ethnic origin, nationality, age, economic position and marital status to the grounds of discrimination that are enumerated. ${ }^{21}$ Among these, the inclusion of 'nationality' is of particular significance, as it reflects the Convention's character as an instrument concerning migration.

The inclusion of 'nationality' in Article 7 distinguishes the Migrant Workers Convention from other instruments. In the case of Article 2(2) ICESCR, the Committee on Economic, Social and Cultural Rights has had to read 'nationality' into the term 'other status'. ${ }^{22}$ By comparison, the merit of the Convention's approach is that 'nationality' is referred to expressly, removing the need for it to be read into the Convention in this way. The inclusion of 'nationality' also differentiates the Convention from the International Convention on the Elimination of All Forms of Racial Discrimination (ICERD). Article 1(1) ICERD does not list 'nationality' as a form of 'racial discrimination', which instead covers 'any distinction, exclusion, restriction or preference based on race, colour, descent, or national or ethnic origin'. Moreover, Article 1(2) ICERD expressly states that the Convention does not address differentiation by states 'between citizens and non-citizens'. In contrast, the advantage of the Migrant Workers Convention is precisely that many of its provisions aim at securing the equal treatment of foreign nationals.

\section{Civil rights in Part III}

Part III of the Convention lists the rights that are applicable to all migrant workers and their families, irrespective of the lawfulness of their stay and/or employment. The criticism that the Convention overlaps unnecessarily with other instruments concerns in particular the civil rights listed in Part III, relative to the equivalent provisions of the ICCPR. ${ }^{23}$ Can the inclusion of these rights nevertheless be justified? ${ }^{24}$

20 See too the discussion in Cholewinski, Migrant Workers in International Human Rights Law, 155.

21 This point is also made by Isabelle Slinckx in 'Migrants' Rights in UN Human Rights Conventions' in De Guchteneire, Pécoud and Cholewinski (eds), Migration and Human Rights, $122-49$, at 146 .

${ }_{22}$ Committee on Economic, Social and Cultural Rights, General Comment No. 20: Nondiscrimination in Economic, Social and Cultural Rights (2 July 2009), UN Doc. E/C.12/GC/20, para. 30.

${ }^{23}$ The term 'civil right' is understood here to refer to individual freedoms and status rights that potentially apply to all persons. The term 'political right' is understood to refer to freedoms and protections that derive from an attachment to a particular state, or that concern political participation.

24 Nafziger and Bartel, in 'Migration Workers Convention', also compare the civil rights set out in the Convention with the Universal Declaration of Human Rights. The ICCPR is taken as the sole reference point here, because it is a binding instrument. 


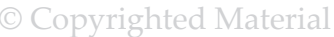

A first point is that Part III of the Migrant Workers Convention includes two rights of direct relevance to migrants that are not set out in the ICCPR. One is the prohibition on confiscation or destruction of identity or immigration documents by anyone other than a public official acting with legal authority (Article 21). The other is the right to consular assistance 'whenever the rights recognized in the present Convention are impaired' (Article 23). The latter of these provisions is complemented by Article 65(2), in Part VI of the Convention, which obliges contracting states to 'facilitate the provision of adequate consular and other services' to migrant workers and their families.

Secondly, where there are overlaps of subject matter, the migration context is often reflected in stronger statements in the Migrant Workers Convention. Protection against expulsion offers a clear example. Article 13 ICCPR provides that a foreign national may be expelled only on the basis of decision reached in accordance with the law, that they should ordinarily be allowed to submit the reasons against the expulsion, and that there should be the possibility of review by a competent authority. By comparison, Article 22 of the Convention is stronger in its substance: collective expulsions are prohibited, expulsion decisions are required to be in a language the individual understands, a written decision setting out the reasons for the expulsion may be requested, and it should be possible to apply for the suspension of an expulsion while a legal challenge to it is pending. Moreover, there is a crucial difference in personal scope. Article 22 extends protection to all migrant workers and their family members, irrespective of the legality of their stay. By contrast, the benefit of Article 13 ICCPR is limited to foreign nationals 'lawfully in the territory of a State Party' ${ }^{25}$

Many other illustrations may be given of stronger statements in the Convention, due to its concern with the position of migrants. Article 8(2) of the Convention states, 'Migrant workers and members of their families shall have the right at any time to enter and remain in their State of origin.' In presenting the right of entry and residence in absolute terms, Article $8(2)$ goes beyond the equivalent Article 12 ICCPR, which provides that a person may not be 'arbitrarily deprived of the right to enter his own country'. ${ }^{26}$ Another case is the provision for the right to liberty and security of the person in Article 16 of the Convention. It goes beyond Article 9 ICCPR in requiring that identity checks by state officials 'be carried out in accordance with procedure established by law', and in providing for access to consular assistance and for interpreters in proceedings concerning the legality of detention. A further example is Article 17 of the Convention, which requires that detention be lawful and legitimate. It goes beyond Article 10 ICCPR in providing that persons detained for violation of immigration rules 'shall be held, in so far as practicable, separately from convicted persons or persons detained pending trial', and in providing that migrants should not bear the cost of detention aimed at verifying compliance with immigration law.

Thirdly, even where the Convention is substantively similar to other instruments, the civil rights set out in Part III are likely to be of particular value to migrants. A good example is the provision in Article 29: 'Each child of a migrant worker shall have the right to a name, to registration of birth and to a nationality'. Other cases are the provisions in the Convention for

25 This key difference between Article 22 ICRMW and Article 12 ICCPR was not referred to in the summary in Nafziger and Bartel, ibid., 791.

26 Emphasis added. In their summary, Nafziger and Bartel did not refer to this key difference between Article 8 ICRMW and Article 12 ICCPR: ibid., 790. 
freedom from slavery, servitude and forced labour, freedom of thought and religion, the right to a fair trial, the principle that criminal offences should not be retroactive, the rule against imprisonment for breach of a contractual obligation, and the right to freedom of association. ${ }^{27}$ All of these rights are potentially of particular value for foreign nationals and their family members, simply because they may be in a weaker social or legal position than the established population of the state in question.

\section{Economic and social rights in Part III}

Criticisms concerning overlap also cover the economic and social rights of migrant workers and their families set out in Part III of the Migrant Workers Convention. In response, an initial point is that two economic and social rights listed in Part III do not appear in the ICESCR. One is the right not to be arbitrarily deprived of property. ${ }^{28}$ The other is the right to transfer earnings, savings and personal property abroad when the period of residence comes to an end. ${ }^{29}$

The economic and social rights in Part III of the Convention are anyway quite different in content to their equivalents in the ICESCR. That is because the Convention provisions generally aim at equal treatment on grounds of nationality, whereas the ICESCR provisions concern the substance of the right at issue. For example, Article 25 of the Convention provides for equal treatment in remuneration and terms and conditions of employment, whereas Article 7 ICESCR provides for 'just and favourable conditions of work'. Article 27 provides for equal treatment in matters of social security, whereas Article 9 ICESCR sets out 'the right of everyone to social security'. Article 28 provides for equal treatment in respect of medical care that is urgently needed in serious cases, whereas Article 12 ICESCR articulates 'the right of everyone to the enjoyment of the highest attainable standard of physical and mental health'. Finally, Article 30 provides for equal access to schooling by migrants' children, as compared to 'the right of everyone to education' in Article 13 ICESCR.

This focus on equality of treatment is logical in an instrument that is concerned with the position of migrants, and not with the advancement of economic and social rights as such. Part III of the Convention need not imply a lower standard of protection, however. The reason is that the rights set out in the ICESCR are not absolute standards. Rather, the duty on a state party to the ICESCR is 'to take steps ... to the maximum of its available resources, with a view to achieving progressively the full realization of' those rights (Article 2(1) ICESCR). In practice, one consequence is that equal treatment is also a central principle within the ICESCR framework, including for foreign nationals. In the words of the Committee on Economic, Social and Cultural Rights, 'the ground of nationality should not bar access to Covenant rights' and 'the Covenant rights apply to everyone including non-nationals, such as refugees, asylumseekers, stateless persons, migrant workers and victims of international trafficking, regardless of legal status and documentation.' ${ }^{30}$

\footnotetext{
${ }_{27}$ Articles 11, 12, 18, 19, 20 and 26 ICRMW, respectively.

28 Article 15 ICRMW.

29 Article 32 ICRMW.

30 Committee on Economic, Social and Cultural Rights, General Comment No. 20, para. 30.
} 


\section{Irregular Migrants}

The second line of criticism of the Convention has been that it gives insufficient protection to irregular migrants. This critique has two elements: that irregular migrants have fewer rights than those in a lawful position, and that they are vulnerable to expulsion. These two arguments are addressed in turn here.

\section{Fewer rights}

Part IV of the Convention confers a number of rights solely upon migrant workers and their family members 'who are documented or in a regular situation'. The distinction drawn within the Convention between the rights of irregular migrants and those of persons in a regular position led to Linda Bosniak's criticism in 1991 that, 'under the terms of Convention, the undocumented continue to enjoy institutionally-sanctioned second- (or third-) class status.' ${ }^{31}$

One point that may be made in response is that the Convention achieves a great deal for irregular migrants. ${ }^{32}$ In three cases, protection is expressly extended to irregular migrants: Article 25 on equal treatment in employment, Article 28 on emergency medical care, and Article 30 on the schooling of children. More generally, the very fact that the Convention's rights are divided between two Parts itself removes any doubt as the application of Part III rights to irregular migrant workers and their families.

A second point is that many of the rights set out in Part IV concern the detail of immigration status, and as such are logically applicable only to 'regular' migrants. That is the case with several provisions concerning the movement and residence of migrants workers and their families: the right to temporary absence from the state in question (Article 38), the right to liberty of movement and residence throughout the territory (Article 39), and the principle that expulsion should not be intended to deprive a person of the benefit of their permission to reside or to work (Article 56(2)). ${ }^{33}$ The same may be said of certain rights conferred on migrant workers: protection of the right of residence in the event of loss of employment (Article 51), free choice of employment after a maximum of five years (Article 52), equal protection in the event of loss of employment (Article 54), and equal treatment in the exercise of employed activity (Article 55). It is also true of requirements concerning migrants' family members: 'facilitation' of admission (Article 44 ), access to the labour market (Article 53), and 'favourable consideration' to their staying after the death of a migrant worker or the dissolution of a marriage (Article 50).

Criticism concerning the exclusion of irregular migrants is more persuasive in relation to Part IV rights that could in principle have been extended to them, but were not. One example is the right to participation in the political affairs in the state of origin, including the right to vote and to be elected there (Article 41). Another is the right to equal treatment

31 Linda Bosniak, 'Human Rights, State Sovereignty, and the Protection of Undocumented Migrants under the International Convention for the Protection of the Rights of All Migrant Workers and Members of Their Families' (1991) 25 International Migration Review 737-70, at 759.

32 For this point, see Slinckx, 'Migrants' Rights in UN Human Rights Conventions', 146-7.

33 Note that the right to liberty of movement and residence is also limited to those 'lawfully in the territory' in Article 12 ICCPR. 


\section{Copyrighted Material}

in education, vocational provision, housing, 'social ... services', access to cooperatives and self-managed enterprises, and in cultural life (Article 43). Other cases concern personal finances: exemption from import and export duties and taxes when international migration occurs, freedom to transfer earnings and savings to the state of origin or elsewhere, and equal treatment in taxation (Articles 46-8). The provision that expulsion should only be for reasons defined in national legislation (Article 56(1)) could logically apply to irregular migrants as well.

In two cases, indeed, the exclusion of irregular migrants from Part IV rights appears inconsistent with other international treaties. One case is the Convention's provision for trade union rights. Article 26 of the Convention (in Part III) recognizes three rights for all migrant workers: '(a) to take part in meetings and activities of trade unions ... with a view to protecting their economic, social, cultural and other interests', '(b) to join freely any trade union,' and '(c) to seek the aid and assistance of any trade union.' What it omits, however, is the right to form trade unions, which is instead recognized in Article 40 (in Part IV) solely for migrant workers in a regular situation. This non-recognition of the right of irregular migrant workers to form trade unions is inconsistent with Article 2 of ILO Convention 87 on the freedom of association, which provides that 'workers and employers, without distinction whatsoever, shall have the right to establish and ... to join organisations of their own choosing. ${ }^{34}$ The Migrant Workers Convention is also at odds with Article 22 ICCPR, which states that 'everyone shall have ... the right to form and join trade unions', and with Article 8 ICESCR, which refers to 'the right of everyone to form trade unions and join the trade union of [their] choice'.$^{35}$

The second case is that of rights concerning healthcare. Article 28 of the Convention (in Part III) recognizes the right of all migrant workers and their family members to equal treatment in 'medical care that is urgently required for the preservation of their life or the avoidance of irreparable harm to their health.' A full right to equal treatment in 'access to ... health services' - extending to cases where medical treatment is not urgently required, or the consequences of its non-provision are not serious - is recognized by Article 43(1) (e) (in Part IV) only for migrants in a regular situation. This is contrary to the provision in Article 12 ICESCR for 'the right of everyone to the enjoyment of the highest attainable standard of physical and mental health', read in light of the equal treatment guarantee in Article 2(2) of that Convention (discussed above). ${ }^{36}$

34 The Committee on Freedom of Association has confirmed that Article 2 of ILO Convention 87 applies to all workers, irrespective of their immigration status: see Spain (Case No 2121) (23 March 2001) Report of the Committee on Freedom of Association No. 327 (Vol. LXXXV 2002 Series B No. 1), paras 561-2 and Republic of Korea (Case No 2620) (18 December 2007) Report of the Committee on Freedom of Association No. 353 (Vol. XCII 2009 Series B No. 1), para. 788.

35 The use of the term 'everyone' in these Articles implies that the regularity of stay or employment should be irrelevant to these rights: see Cholewinski, Migrant Workers in International Human Rights Law, 164.

36 See Committee on Economic, Social and Cultural Rights, General Comment No. 14: The Right to the Highest Attainable Standard of Health (2000), para. 34. For a discussion, see Vincent Chetail and Gilles Giacca, 'Who Cares? The Right to Health of Migrants' in Andrew Clapham and Mary Robinson (eds), Realising the Right to Health (Rueffer, Zurich, 2009) 224-34. 


\section{Immigration policy and control}

The Convention's acceptance of immigration control was a second reason for criticism of its treatment of irregular migrants by Bosniak in 1991. As she put it, 'the real problem with the Convention ... is that its provisions protecting states' sovereign prerogatives to control immigration will often effectively undermine or defeat the rights it provides to those migrants. ${ }^{37}$ On close examination, however, it appears that this critique overestimates the weight given to immigration policy and control within the Convention.

Consider first Article 68 of the Convention. It obliges states to 'collaborate with a view to preventing and eliminating' irregular movements of persons and the irregular employment of migrant workers, and to 'take all adequate and effective measures to eliminate employment ... of migrant workers in an irregular situation. ${ }^{\prime 38}$ Bosniak's interpretation of Article 68 was that it required states 'to undertake control measures to end the process of clandestine migration and the ... employment of irregular migrants including ... employer sanctions' ${ }^{39}$ The difficulty with this reading is that Article 68 does not use the language of 'control'. Its language of 'preventing' and 'eliminating' potentially covers both control measures and preemptive policies designed to remove the basis for irregular migration. Pre-emptive policies would generally be beneficial to migrants, including those who are, or would otherwise be, in an irregular position.

Policy on regularization is another example. Article 69(1) of the Convention sets out the general proposition that, 'when there are migrant workers and members of their families within their territory in an irregular situation', contracting states 'shall ... take appropriate measures to ensure that such a situation does not persist'. Bosniak's reading was that Article 69 required states 'to undertake control measures to end ... the presence ... of irregular migrants. ${ }^{40} \mathrm{In}$ reality, control measures aimed at expulsion are only one option for state authorities, who may choose regularization instead. ${ }^{41}$ Indeed, Article 69(2) expressly provides that states may 'consider the possibility of regularizing the situation of such persons', and requires that, where they do so, 'appropriate account shall be taken of the circumstances of their entry, the duration of their stay in the States of employment and other relevant considerations, in particular those relating to their family situation.' Bosniak also cited Article 35 of the Convention as evidence that 'contracting states are explicitly not obliged to regularize the status of irregular migrant workers. ${ }^{\prime 2}$ In fact, Article 35 provides only that 'nothing in the present Part of the Convention [i.e. Part III] shall be interpreted as implying ... regularization', ${ }^{43}$ and is stated to be without prejudice to Part VI of the Convention, which includes Article 69.

Two further provisions of the Convention may be discussed more briefly. One is Article 34 of the Convention, which provides that ' $[\mathrm{n}]$ othing in [Part III] of the Convention shall have the

37 Bosniak, 'Human Rights, State Sovereignty', 759.

38 Emphasis added.

39 Bosniak, 'Human Rights, State Sovereignty', 741, emphasis added.

40 Ibid., 741.

41 For example, De Guchteneire and Pécoud have noted that Article 69 'may be interpreted as an obligation to either expel or regularize undocumented migrants': Paul de Guchteneire and Antoine Pécoud, 'Introduction: The UN Convention on Migrant Workers' Rights' in De Guchteneire, Pécoud and Cholewinski (eds), Migration and Human Rights, 1-44, at 22-3.

${ }_{42}$ Bosniak, 'Human Rights, State Sovereignty', 741.

43 Emphasis added. 
effect of relieving migrant workers and the members of their families from ... the obligation to comply with the laws and regulations of any State of transit and the State of employment.' In Bosniak's analysis, this provision covered 'states' laws against unauthorized entry, employment or residence. ${ }^{\prime 4}$ Article 34 can also be read more narrowly, however, to require migrants to comply with the law in general, while obliging states to respect the substantive provisions of the Convention. The other is Article 79, which provides that 'nothing in the present Convention shall affect the right of each State Party to establish the criteria governing admission of migrant workers and members of their families.' Bosniak's characterization of Article 79 was that it permitted 'states parties to pursue the immigration control policies that they see fit' ${ }^{45}$ It would, however, be more accurate to say that Article 79 is concerned solely with the criteria for admission, and that it does not refer to states' immigration control methods.

The wider point is that the Convention does not give carte blanche to states in their immigration control systems. States remain free to have immigration policies, and to take immigration control measures in support of them. But the provision for an orderly approach to international migration in Articles 68 and 69 may equally imply acceptance of migration. Moreover, certain of the substantive rights of migrants - particularly those in Part III - may impact on immigration control measures applied to irregular migrants. We shall see in section 2 how this is an area in which the Committee on Migrant Workers has been especially creative in its interpretative work to date.

\section{The Convention in Practice}

Where section 1 considered the content of the Convention in the abstract, this section will consider its application in practice. The extent and pattern of ratification of the Convention are considered first, as these have been a particular area of doubt concerning its prospects. The section will then provide a detailed analysis of the work of the Committee on Migrant Workers to date.

\section{Ratification}

Forty-four states had ratified the Migrant Workers Convention at the time of writing (May 2011). Of these, the largest concentration by continent is in the Americas, where 17 out of 35 UN members have ratified the Convention. ${ }^{46}$ There has also been extensive ratification in Africa, where 17 of $53 \mathrm{UN}$ member states are parties, primarily in North and West Africa ${ }^{47}$ By

\footnotetext{
44 Bosniak, 'Human Rights, State Sovereignty', 741.

45 Ibid., emphasis added.

46 These are Argentina, Belize, Bolivia, Chile, Colombia, Ecuador, El Salvador, Guatemala, Guyana, Honduras, Jamaica, Mexico, Nicaragua, Paraguay, Peru, Saint Vincent and the Grenadines and Uruguay.

47 The full list of African states to have ratified is Algeria, Burkina Faso, Cape Verde, Egypt, Ghana, Guinea, Lesotho, Libya, Mali, Mauritania, Morocco, Niger, Nigeria, Rwanda, Senegal, Seychelles and Uganda.
} 
contrast, only six Asian states of $43 \mathrm{UN}$ members and only four European states out of $47 \mathrm{UN}$ members have ratified, while none of the $14 \mathrm{UN}$ members in Oceania have done so. ${ }^{48}$

The low level of ratification of the Convention has contributed to doubts as to its true value. Unfavourable comparisons have been drawn with other specific UN human rights instruments, including the Convention on the Elimination of Discrimination against Women (adopted in 1979), which had 186 parties at the time of writing, and the Convention on the Rights of the Child (adopted in 1989), which had 190, and with the Migrant Smuggling Protocol (adopted in 2000), which had 127 parties at the time of writing. ${ }^{49}$ In itself, however, this relatively low level of ratification does not tell us whether the Convention has value for those states that are parties.

The lack of ratification by the major countries of immigration in Europe, North America and elsewhere has been seen as a further weakness. Writing in 2009, Paul de Guchteneire and Antoine Pécoud put it bluntly: 'no major state has ratified, which strongly diminishes the impact of the Convention. ${ }^{50}$ There is, however, a risk of what may be termed 'North-centrism' in discussion of the Convention. This bias is reflected in the extensive research (including by the present author) into obstacles to ratification in highly developed countries. ${ }^{51}$ The danger is that scholarship on the Convention is blind to its potential outside the most developed group of states. It is striking in particular that the experience of countries that have ratified has remained largely unexamined in academic commentary to date..$^{52}$

One reason why the Convention may have value as a source of standards for countries that have ratified is that many of those states have extensive experience of emigration. For example, the many Latin American states that have ratified are countries of origin, as are the North and West African states that have done so, the Philippines and Sri Lanka in Asia, and Albania and Turkey in Europe. States of origin that have ratified may have intended thereby to boost the Convention, in order to secure better treatment for their nationals in destination countries. ${ }^{53}$ But the text of the Convention also places duties upon them. We shall see below that this latter aspect has been prominent in the work of the Committee on Migrant Workers to date.

48 The Asian states to have ratified are Kyrgyzstan, Philippines, Sri Lanka, Syria, Tajikistan and Timor Leste. The four European states to have ratified are Albania, Azerbaijan, Bosnia and Herzegovina and Turkey. (Membership of the Council of Europe has been used to define the category of 'European' state here.)

49 De Guchteneire and Pécoud, 'Introduction', 11-12, 24-5.

50 Ibid., 13. In the same collection, Carla Edelenbos expressed frustration at the 'absence of any major receiving country among the States Parties': 'Committee on Migrant Workers and Implementation of the ICRMW' in De Guchteneire, Pécoud and Cholewinski (eds), Migration and Human Rights, 100-121, at 119.

51 See, for example, Shirley Hune and Jan Niessen, 'Ratifying the UN Migrant Workers Convention: Current Difficulties and Prospects' (1994) 12 Netherlands Quarterly of Human Rights 130-41, and the studies on Canada, France, Germany, Italy and (by the present author) the United Kingdom in De Guchteneire, Pécoud and Cholewinski (eds), Migration and Human Rights.

52 For a similar observation, see Chetail, 'Review of Migration and Human Rights', 680. An exception is the chapter by Gabriela Díaz and Gretchen Kuhner, 'Mexico's Role in Promoting and Implementing the ICRMW' in De Guchteneire, Pécoud and Cholewinski (eds), Migration and Human Rights, 219-46.

53 See Battistella, 'Migration and Human Rights', 59. 
Secondly, many states that have ratified the Convention have experienced significant levels of transit migration. The wider picture is that, since the mid-1980s, the most developed countries have taken a more rigorous approach to immigration control, including through tougher visa policies and the introduction of carrier sanctions. As a result, their neighbouring states have often faced an increase in arrivals by persons in transit. Among states that have ratified the Convention, this has been the case in particular for Mexico (mainly in relation to Central America), for Algeria, Egypt, Libya and Morocco (mainly in relation to sub-Saharan Africa) and Turkey (mainly in relation to Asian countries). ${ }^{54}$ When those neighbouring states are parties to the Convention, they are bound by its terms in their treatment of transit migrants who are migrant workers or their family members.

Thirdly, a number of states that are parties to the Convention are migration destinations in their own right. Among the states that have ratified, Argentina and Libya stand out as countries - for quite different reasons - with long histories of inward migration for employment. ${ }^{55}$ The emergence of a migrant population is also a feature of conditions in Chile, Ecuador and Uruguay. ${ }^{56}$ More generally, all of the 'transit' countries and regions referred to above are potential destination countries, if those who initially intend to move on to North America or Western Europe elect to remain there. ${ }^{57}$

The relevance of the Convention to the migration experience of ratifying states has been recognized in the work of the Migrant Workers Committee. In its observations on the state reports submitted to it (see below), it has frequently noted that the state in question, in addition to being a state of origin, is also a place of transit and/or of destination. Statements of this kind have been included in the concluding observations concerning all five Latin American states considered to date (Bolivia, Colombia, Ecuador, El Salvador and Mexico), as well as three African states (Algeria, Egypt and Senegal) and two European states (Azerbaijan and Bosnia and Herzegovina). In three further cases, there has been partial recognition that the party was not merely a country of origin: Albania was described as a country of origin and transit; Mali was said to have difficulties in controlling irregular migration; and it was noted that Syria had recently experienced extensive migration as a result of the armed conflict in Iraq. Of the fifteen countries commented upon so far, only the Philippines and Sri Lanka have been characterized by the Committee as states of origin alone.

54 See generally Manuel Ángel Castillo, 'Mexico: Caught between the United States and Central America' (Migration Information Source, April 2006) and Franck Düvell 'Crossing the Fringes of Europe: Transit Migration in the EU's Neighbourhood' (COMPAS Working Paper WP06-33, 2006).

55 See Maia Jachimowicz, 'Argentina: A New Era of Migration and Migration Policy' (Migration Information Source, January 2006) and Sara Hamood, African Transit Migration through Libya to Europe: The Human Cost (American University in Cairo, 2006) 17-19.

56 See Agustín Escobar Latapí, The Future of Migration Policies in the Americas (IOM, Geneva, 2010) 7 .

57 See Michael Colyer and Hein de Haas, 'Developing Dynamic Categorisations of Transit Migration' (2011) 17 Population, Space and Place 468-81. 


\section{The Committee on Migrant Workers}

The Committee on Migrant Workers is provided for in Article 72 of the Convention. It was established on 1 January 2004, six months after the Convention came into force. The distribution of its current 14 members broadly corresponds to the geographical spread of ratifications, with five American states (Ecuador, El Salvador, Jamaica, Guatemala and Mexico), five African states (Burkina Faso, Egypt, Morocco, Mali and Senegal), two Asian states (the Philippines and Sri Lanka), and two European states (Azerbaijan and Turkey).

The Convention provides for two optional procedures through which complaints may be brought to the Committee. Participating states may recognize the Committee's competence over interstate complaints (Article 76), and over complaints by 'individuals subject to its jurisdiction' who claim their rights have been violated by that state (Article 77). ${ }^{58}$ Each of these procedures is to come into effect when ten states have accepted the competence of the Committee. At the time of writing, only Guatemala had made the necessary declaration with respect to Article 76, while only Guatemala and Mexico had done so with respect to Article 77. In addition, Turkey has declared that it will recognize the competence of the Committee 'at a later time'.

Accordingly, the Committee's most significant role to date has been its consideration of state reports, made under Article 73, on the 'legislative, judicial, administrative and other measures' taken to give effect to the Convention. A contracting state is to submit the first such report within one year of the entry into force of the Convention for it. Subsequently, reports should be submitted every five years, or 'whenever the Committee so requests'. By early 2011, 20 states had submitted initial reports to the Committee, and two states (Mexico and Ecuador) had reported a second time. ${ }^{59}$ In total, 15 initial state reports, and both of the second periodic reports, had been the subject of concluding observations by the Committee. ${ }^{60}$ As against that, 22 states had failed to submit a required initial report as of early $2011,{ }^{61}$ while a further four states had failed to submit second periodic reports that were due in 2009 or $2010 .{ }^{62}$

The rest of this section will offer an analysis of the Committee's interpretation of the Convention in its concluding observations. It will also discuss the Committee's only General Comment to date, on migrant domestic workers (General Comment No. 1, 2010). ${ }^{63}$ Rather than an exhaustive summary, what will be provided is a thematic account of the major issues that

58 Article 77(2) makes it a precondition to the Committee's considering an individual complaint that 'the same matter has not been, and is not being examined under another procedure of international investigation or settlement'. This replicates the language of Article 5(2) of the First Optional Protocol to the ICCPR, which gives the Human Rights Committee jurisdiction over individual complaints.

59 The states that had submitted initial reports by the end of 2010 were: Albania, Algeria, Argentina, Azerbaijan, Bolivia, Bosnia and Herzegovina, Chile, Colombia, Guatemala, Ecuador, El Salvador, Egypt, Mali, Mexico, Paraguay, the Philippines, Senegal, Sri Lanka, Syria and Tajikistan.

${ }^{60}$ At the time of writing, the reports by Argentina, Chile, Guatemala, Paraguay and Tajikistan had not been the subject of concluding observations.

61 Note that Guyana and St Vincent and the Grenadines each ratified the Convention during 2010, and were therefore obliged to submit an initial report only in 2011.

62 These were Bolivia, Egypt, El Salvador and Mali.

63 The only similar analysis of which the author is aware is the discussion of the Committee's first three sets of concluding observations in Edelenbos, 'Committee on Migrant Workers'. 


\section{O Copyrighted Material}

have emerged, grouped under the following headings: the position of emigrants, the rights of immigrants, and immigration policy and control. ${ }^{64}$

\section{The Position of Emigrants}

As all of the states whose reports have been considered to date are countries of origin of migrants, the Committee's observations have frequently addressed their relationship with emigrant nationals. ${ }^{65}$ It has focused on three topics in particular: the right to leave, the representation of nationals abroad, and political rights.

\section{The right to leave}

Article 8 of the Convention provides for the right of migrant workers 'to leave any State, including their State of origin'. The Committee relied upon Article 8 to question Ecuador's (2007) requirement that its nationals obtain an exit permit in order to leave the territory. ${ }^{66}$ In addition, while not referred to explicitly, Article 8 was presumably the basis for the Committee's recommendation to Egypt (2007) that women should be able to obtain passports without the approval of a husband or male relative. ${ }^{67}$

The Committee has also taken the view that states ought not to criminalize irregular exit with the aim of deterring migrant smuggling. In its concluding observations on Algeria (2010), the Committee recommended reconsideration of a legislative proposal to criminalize departure other than through a border post, for which the proposed maximum penalty was a period of imprisonment of six months. ${ }^{68}$ That recommendation was adopted with reference, not to Article 8, but to Part VI of the Convention, which concerns 'orderly' migration. The Committee also suggested that penalties were contrary to the Migrant Smuggling Protocol of 2000 (to which Algeria is a party), presumably because its Article 5 prohibits 'criminal prosecution' of migrants 'for the fact of having been the object of' smuggling. ${ }^{69}$

\section{Representation of nationals abroad}

The Committee has also supported the conclusion of bilateral arrangements by states of origin with states of employment. In the case of Sri Lanka (2009), it 'note[d] with interest the memoranda of understanding and bilateral agreements with major labour receiving

64 The concluding observations will be cited below by giving the state name and the year of the document in which the observations were published.

65 For a similar observation, see Edelenbos, 'Committee on Migrant Workers', 120-21.

66 Ecuador, 5 December 2007, para. 22. In 2010, Ecuador reported that the exit permit requirement had been ruled unconstitutional, and that it was no longer in force: Ecuador: Second Periodic Report, 26 January 2010, para. 122.

67 Egypt, 25 May 2007, paras 26-7.

68 Algeria, 19 May 2010, paras 40 and 41. Details of the legislation are in 'Algeria: Comments by the State Party', 3 May 2010.

69 In a written response, Algeria argued that its proposed legislation aimed to uphold human dignity and the right to life, and to prevent human trafficking: 'Algeria: Comments by the State Party', 3 May 2010. 
countries' ${ }^{70}$ Similarly, the Committee welcomed Ecuador's (2010) signature of ten 'alliances and agreements' with other countries for the protection of its nationals abroad. ${ }^{71}$ By contrast, the Committee called upon Egypt (2007) to negotiate with Gulf states for the abolition of legal arrangements there that gave sponsors personal control over its nationals. ${ }^{72}$ Similar recommendations concerning the protection of migrant workers in Gulf states were made to Syria (2008) and to the Philippines (2009). ${ }^{73}$ It may be added that the Committee has mainly based these observations on Part VI of the Convention, which aims at 'orderly' international migration. ${ }^{74}$

The Committee has also emphasized the importance of effective consular support for contracting states' nationals. One aspect of such support is the provision of assistance to migrant workers who have grievances arising out of their employment. The Committee recommended that the Philippines (2009) 'ensure that its embassy and consulate staff abroad are knowledgeable about the laws and procedures of the countries of employment of Filipino foreign workers' ${ }^{75}$ Similarly, it encouraged Sri Lanka (2009) to ensure that legal assistance was available to migrant workers in all its embassies and consulates, and that its labour welfare officers were knowledgeable about the labour laws and procedures of the country of deployment. ${ }^{76}$ A second aspect of consular assistance that the Committee has highlighted is the timely provision of travel documents to their nationals who face expulsion from another country. Egypt (2007) and Bolivia (2008) have each been criticized for systematic failures in this regard. ${ }^{77}$ These various observations have been made either under Part III of the Convention, or - in the sole case of Egypt - under Part VI. This implies that they were based on Article 23 and Article 65 of the Convention, respectively (see section 1, above).

\section{Political rights}

The Committee has also sought to promote compliance with the right of emigrant workers in a regular position to vote in elections in their state of origin (Article 41 of the Convention). Failures to respect this right in the state's electoral rules were identified in two cases: the Philippines (2009), which allowed the right to vote only to those who affirmed their intention to return within three years, and Albania (2010), which allowed voting to take place solely on its territory. ${ }^{78}$ In seven other cases, the Committee has called for the contracting state to take steps to facilitate the practical exercise of the right to vote by its nationals abroad. ${ }^{79}$

70 Sri Lanka, 19 October 2009, paras 39-40.

71 Ecuador, 15 December 2010, para 5.

72 Egypt, 25 May 2007, paras 48-9.

73 Syria, 2 May 2008, para. 38; The Philippines, 22 May 2009, para. 32.

74 The observations on Sri Lanka, Egypt and Syria were made under Part VI. The observation concerning Ecuador was listed under 'positive aspects', without further elaboration. The observation on the Philippines was based on Part III.

75 The Philippines, 22 May 2009, para. 30.

76 Sri Lanka, 19 October 2009, para. 30.

77 Egypt, 25 May 2007, paras 46 and 47; Bolivia, 29 April 2008, para. 28.

78 The Philippines, 22 May 2009, paras 35-6; Albania, 26 November 2010, paras 31-2.

79 Mali, 31 May 2006, para. 7; Egypt, 25 May 2007, para. 43; Bolivia, 29 April 2008, para. 34; El Salvador, 4 February 2009, para. 35; Colombia, 22 May 2009, para. 34; Bosnia and Herzegovina, 3 June 2009, para. 30; Sri Lanka, 19 October 2009, para. 34. 


\section{The Rights of Immigrants}

Given the focus of the Convention on the treatment of migrant workers and their family members, it is not surprising that the rights of immigrants have been central to the work of the Committee to date. The discussion here considers the Committee's comments in four areas: personal status, access to labour law, trade union rights, and social provision for irregular migrants.

\section{Personal status}

We saw above that Article 29 of the Convention confers 'the right to a name, to registration of birth and to a nationality' upon children. Relying upon that Article, the Committee has addressed recommendations to three states concerning the registration of births. It expressed its regret that children born in Egypt (2007) to migrant workers, whether in a regular or an irregular situation, were unable to obtain birth certificates ${ }^{80}$ It expressed concern at the number of children of migrants in Ecuador (2007) whose births were not registered 'either because their parents fail to register them for fear of being deported or because their registration is refused on the ground of the irregular status of one or both parents. ${ }^{81}$ Similarly, it expressed concern at refusals by many officials in Mexico (2011) to register the births of the children of irregular migrants, notwithstanding that they were Mexican citizens by birth. ${ }^{82}$

In a further case, the Committee addressed the right to a nationality. Having noted that only children with a parent domiciled in Colombia (2009) were eligible for Colombian nationality, it expressed concern that some children might remain stateless as a result. It therefore recommended that the state ensure the right of all children to a nationality, and that it proceed with its proposed accession to the 1961 United Nations Convention on the Reduction of Statelessness. ${ }^{83}$

\section{Access to labour law}

The Committee has interpreted the Convention to require that migrants have access to the protection of labour law both in theory and in practice. The starting point is that Article 25(1) of the Convention provides that 'migrant workers shall enjoy treatment not less favourable than that which applies to nationals of the State of employment' in respect of terms and conditions of employment. Article 25(2) makers clear that this guarantee of equal treatment applies within individual employment relationships, by providing that 'it shall not be lawful to derogate in private contracts of employment from the principle of equality of treatment'.

\footnotetext{
80 Egypt, 25 May 2007, para. 34.

81 Ecuador, 5 December 2007, para. 35.

82 Mexico, 8 April 2011, para. 39.

83 Colombia, 22 May 2009, paras 29-30. The 1961 Convention had not been ratified as of May 2011. Note that ratification would not imply an unlimited right to the nationality of the state of birth for those who are otherwise stateless. In particular, where a child born on the territory was born to foreign parents, Article 1 of the 1961 Convention permits parties to set a minimum age, up to 18 , for an application, and to make the grant of nationality conditional upon the person's habitual resided in the territory for up to 10 years.
} 
The Committee relied specifically upon Article 25 in criticism of Egypt (2007) for an apparent requirement of reciprocity before its Labour Code applied to legally employed foreign workers. ${ }^{84}$ The Committee also referred to it in General Comment No. 1 (2010), when stating that migrant domestic workers 'should enjoy treatment not less favourable than that which applies to nationals of the State of employment'..$^{5}$

The Committee's has also called for the inclusion of migrant domestic workers within labour law in its comments on Egypt (2007) and in General Comment No. 1 (2010) ${ }^{86}$ In the case of Egypt, its observations were made under Part III of the Convention, without further explanation. In General Comment No. 1, it simply referred in general to 'equal protection under the law' as a conceptual basis for the inclusion of domestic workers within labour law, even though that principle does not appear in the text of the Convention. The Committee presumably did not refer to Article 25 in these observations because that Article requires the equal treatment of migrants, which may be thought to provide an insufficient basis to challenge the exclusion of an entire category of worker from some or all labour laws.

The Committee has also addressed the question of limited access to labour law protections by irregular workers. The background is that Article 25(3) of the Convention contains two propositions of relevance to their position - that irregularity may not be a ground for depriving migrant workers of equal treatment, and that 'employers shall not be relieved of any legal or contractual obligations' because of a worker's 'irregularity of stay or employment'. To date, the Committee has, however, relied upon this Article only by implication, preferring instead to base its remarks on the position of irregular workers under Article 83 of the Convention, which sets out a right to an effective remedy where Convention rights or freedoms are violated. In the case of Mexico (2006), the Committee expressed its concern at a legislative provision that allowed legal proceedings to be instituted by foreign nationals only if they were legally resident. ${ }^{87}$ Lack of access by irregular migrant workers to an effective remedy was also the subject of Committee recommendations to Syria (2008), in relation to its labour commissions, and Algeria (2010), in relation to the courts in general..$^{88}$

Finally, the Committee has sought to promote the practical effectiveness of labour law in relation to particularly vulnerable groups of workers. It recommended that the application of labour law standards be made effective for migrant domestic workers in Mexico (2006), Ecuador (2007 and 2010), El Salvador (2009), and in General Comment No. 1(2010), and for migrant workers in agriculture in Mexico (2006) and El Salvador (2009). ${ }^{89}$ Among these cases,

${ }^{84}$ Egypt, 25 May 2007, paras 30-31. The Government's evidence was that the principle of reciprocity applied only to exemption from the requirement to obtain a work permit: see 'Egypt: Written Replies', 6 February 2007, 16-17.

85 General Comment No. 1 on Migrant Domestic Workers (23 February 2011), UN Doc. CMW/C/GC/1, para. 38.

86 Egypt, 25 May 2007, paras 38-9; General Comment No. 1, para. 38.

87 Mexico, 20 December 2006, paras 25-6. In November 2008, Mexico's Supreme Court ruled that foreign workers were entitled to the protection of labour law, irrespective of their migration status, and, in 2010, the offending legislative provision was removed, so as to permit all legal claims by irregular migrants. See 'Mexico: Second Periodic Report', 14 January 2010, para. 29, and Mexico, 8 April 2011, para. 7(e).

88 Syria, 2 May 2008, paras 25-6; Algeria, 19 May 2010, paras 16-17.

89 Mexico, 20 December 2006, paras 33-4 and 37-8; El Salvador, 4 February 2009, paras 29 and 30; Ecuador, 5 December 2007, para. 38; Ecuador, 15 December 2010, para. 28; General 
the Committee cited Article 25 only in relation to El Salvador (2009). Elsewhere, it has made these comments under general headings - Part IV of the Convention in the case of agricultural workers in Mexico (2006), 'conditions of work' in General Comment No. 1 (2010), and Part III of the Convention in the other cases.

\section{Trade union rights}

We saw in section 1 that trade union rights are provided for in two places in the Convention: Article 26 for all migrant workers, and Article 40 for migrant workers in a regular situation. To date, the Committee has relied upon Article 26 mainly in relation to irregular migrant workers. In the case of Albania (2010), it referred to Article 26 in criticizing a legal provision specifically excluding irregular migrant workers from joining trade unions. ${ }^{90}$ In the case of Algeria (2010), it expressed its concern more generally that irregular workers did not 'effectively enjoy' a range of Convention rights, including the right to join trade unions in Article 26. ${ }^{91}$ An exception - where Article 26 was recognized to apply to all workers - was the statement in General Comment No. 1 (2010) that 'the laws of States parties, particularly countries of employment of migrant domestic workers, should recognize the right of the latter to form and join organizations, regardless of migration status (article 26). ${ }^{\prime 2}$

The Committee has by contrast shown itself more willing to identify a breach of Article 40. In some cases, this has been because of discrimination against foreign nationals in the law relating to trade unions. The Committee concluded that that the reservation of the constitutional right to form trade unions to citizens in Sri Lanka (2009) was a breach both of Article 40 and of the non-discrimination guarantee in Article $7 . .^{93}$ It concluded that the Philippines (2009) was in breach of Article 40 in making the trade union rights of migrant workers subject to a condition of reciprocal treatment of its nationals. ${ }^{94}$ In the case of Algeria (2010), the Committee identified a breach of Article 40 in the exclusion of migrant workers from the right to form trade unions. ${ }^{95}$ On that occasion, it also expressed its concern at the non-exercise by lawful migrant workers of the right to engage in trade union activities under Part IV of the Convention, though without linking its observation to a specific Article. ${ }^{96}$

In four other cases, the Committee has criticized the exclusion of foreign nationals from official positions within trade unions. Mexico (2006, 2011), Ecuador $(2007,2010)$ and El Salvador (2009) all had blanket rules excluding foreign nationals from the leadership of trade unions. In each case, the Committee identified a breach of what it has termed the right to form, and to form part of the leadership of ... trade unions', guaranteed by Article $40 .{ }^{97} \mathrm{In}$ addition, the Committee recommended that Senegal (2010) remove its precondition to migrant

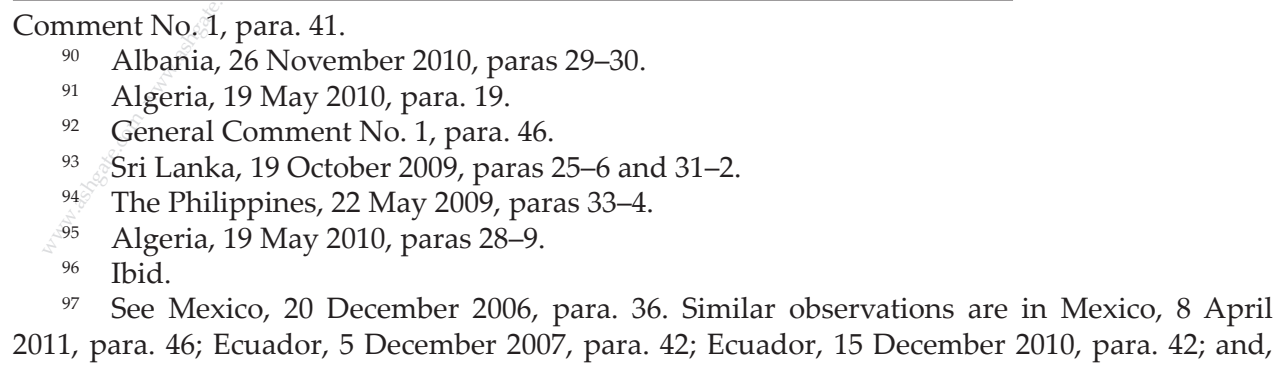


workers serving as trade union officials that there be a reciprocal agreement with the country of nationality. ${ }^{98}$ This recommendation was made under Part IV of the Convention, and by implication was again based on Article 40.

It is significant that, in its comments on trade union rights to date, the Committee has preferred to rely upon Article 40, or Part IV more generally, even though the subject matter of its comments potentially falls within Article 26. For example, the non-participation of lawful migrant workers in trade union activities in Algeria (2010) touched on a matter expressly mentioned in Article 26 alone. Similarly, discrimination against foreign nationals in Sri Lanka, Algeria and the Philippines presumably entailed a denial not just of the right to form trade unions, but also of their Article 26 rights. Equally, the possibility for foreign nationals to be officials or leaders of a trade union could have been classed, not as an aspect of trade union formation, but as 'participation' in trade union activities. Much as with the Convention itself, therefore, the Committee has generally approached trade union rights in a manner that has avoided the fullest protection for irregular migrant workers.

\section{Social provision for irregular migrants}

Three of the provisions in Part III of the Convention referred to in section 1 are of particular relevance to state social provision for irregular migrants. Article 27 provides for the equal treatment of all migrant workers and their family members in the field of social security. Article 28 provides for access to urgent medical care, and expressly covers those whose residence or employment is irregular. Article 30 sets out the right of a child of a migrant worker to equality of access to education, and expressly precludes the irregularity of a parent's residence or employment, or of the child's own residence, from being a reason for denying a child access to schooling.

The Committee has invoked these Articles in relation to irregular migrant workers on four occasions. It called for compliance by Egypt (2007) with Article 30, because of its concern that 'the children of undocumented migrant workers do not have any access to the schooling system, whether public or private. ${ }^{\prime 99}$ It called for Ecuador (2007) to comply with Article 28, because of evidence that 'in practice migrant workers in an irregular situation and members of their families face difficulties in accessing the public health system. ${ }^{\prime 100}$ It called for Azerbaijan (2009) to comply with Articles 28 and 30, because of reports that irregular migrants and their family members did not have access to medical care in practice, and that the children of irregular migrants had difficulty obtaining access to education. ${ }^{101}$ Finally, in the case of Algeria (2010), it listed both Article 27 on social security and Article 28 on medical care among the rights that irregular migrant workers did not 'effectively enjoy'. ${ }^{102}$

El Salvador, 4 February 2009, para. 32. In the case of El Salvador, the right to form part of the leadership was limited to its nationals by birth.

98 Senegal, 10 December 2010, para. 16.

99 Egypt, 25 May 2007, paras 36-7. The Committee also expressed its concern at the lack of access to public schools by the children of legal migrant workers.

100 Ecuador, 5 December 2007, paras 39-40.

101 Azerbaijan, 19 May 2009, paras 30-31.

102 Algeria, 19 May 2010, para. 19. 


\section{Immigration Policy and Control}

We saw in section 1 that the Convention has been criticized for leaving too much scope for states' immigration policy and control. In practice, however, the Committee has taken a more robust view, and has identified ways in which immigration policies and control measures conflict with states' obligations under the Convention. Three issues are addressed here: the treatment of irregular migrants within immigration control systems, regularization, and the content of legal migration policy.

\section{Treatment of irregular migrants within immigration control}

An important subject addressed by the Committee concerning irregular migrants is the detention of those presumed to have breached immigration law. As we saw above, Article 17 of the Convention requires that those suspected of a breach of immigration laws should if possible be detained separately from those within the criminal justice system. The Committee has to date commented on three states' failures to respect the general principle: Mexico (2006), Ecuador (2007) and Senegal (2010). ${ }^{103}$ In the case of Mexico, this recommendation was included under Part III without reference to a particular Article, while, in the other cases, Article 17 was referred to expressly. ${ }^{104}$

In addition, the Committee has twice criticized states for providing criminal sanctions for those who breach immigration law. The Convention does not expressly prohibit criminal penalties, and the Committee has not referred to any particular provision in support of these comments. One possible argument is that the sanction of imprisonment is prohibited by the requirement in Article 17 (above) to keep those who breach immigration law separate from those detained within the criminal justice system. That may explain the Committee's recommendation to Mexico (2006) - under the heading of 'General measures of implementation' - that it 'annul the classification of illegal entry into the country as an offence punishable by deprivation of liberty. ${ }^{\prime 105}$ Alternatively, criminalization as such might be thought incompatible with the effective exercise by irregular migrants of their rights under the Convention. That was the approach taken by the Committee when it called upon Algeria (2009) to ensure that migrant workers and their families were 'not deprived of any of the rights under the Convention which apply to all migrant workers, including those in an irregular situation', and to 'bring its legislation - which criminalizes irregular migration - into conformity with the Convention. ${ }^{\prime 106}$

103 Mexico, 20 December 2006, para. 28; Ecuador, 5 December 2007, para. 24; Senegal, 10 December 2010, para. 15.

104 The recommendation concerning Ecuador referred to Article 17(3). Confusingly, however, that in relation to Senegal referred to Article 17(2). That may have been an error, as that provision is concerned with the rights of 'accused' persons, rather than those suspected of a breach of immigration law.

${ }_{105}$ Mexico, 20 December 2006, para. 15. In line with that recommendation, in its second report, Mexico informed the Committee that its legislation had been amended, so that breaches of immigration law had become the subject of fines alone, and could no longer give rise to a prison sentence: 'Mexico: Second Periodic Report', 14 January 2010, paras 136-7.

106 Algeria, 19 May 2010, paras 18 and 21. 


\section{Regularization}

The Committee has consistently taken the view that a procedure for regularization ought to be available as a solution to irregular status, at least where there are substantial numbers of irregular workers present on a state's territory. It has generally favoured Article 69 (discussed in section 1, above) as the basis for its comments on this subject. For example, it expressed its concern at reports that a high percentage of migrant workers in Azerbaijan (2009) were in an irregular position, and recommended 'appropriate measures, in accordance with the Convention, in particular with Article 69, to ensure that this situation does not persist, including the possibility of regularizing the situation of these migrant workers. ${ }^{\prime 107}$ Article 69 was also cited as the basis for recommending access to regularization for domestic workers in the General Comment on Migrant Domestic Workers (2010). ${ }^{108}$ In addition, in the case of Senegal (2010) the Committee referred to both Articles 68 and 69, before recommending 'proactive and effective measures to ensure that migrant workers and members of their families do not remain in an irregular situation', and that any regularization mechanism should be 'accessible and expeditious' ${ }^{\prime}{ }^{109}$ That joint reference to Articles 68 and 69 is especially significant, as it is in line with the view (discussed above) that these Articles may oblige states to take pre-emptive action to prevent irregular migration and employment.

The Committee has not relied upon Article 69 alone, however. In the cases of Mexico (2006) and Ecuador $(2007,2010)$, it recommended regularization as a means of social and labour market protection for female migrant domestic workers under Part III of the Convention. ${ }^{110}$ Part III was also the heading for a recommendation to Ecuador (2010) to 'redouble its efforts to establish and implement a comprehensive migration regularization policy.' ${ }^{\prime 11}$ Finally, in the case of Bolivia (2008), the Committee inexplicably addressed regularization under Part IV of the Convention, when recommending that an existing regularization procedure be strengthened, through reductions in fees and delays, and by allowing applicants to remain while a decision was taken. ${ }^{112}$

\section{Content of legal migration policy}

Despite the terms of Article 79, which allows contracting states to set admission criteria (see section 1), the Committee has made recommendations to states on several occasions concerning their legal migration policy. One key proposition it has advanced is that a state ought to design its legal migration policy so as to minimize the risks of irregular migration and employment. Azerbaijan (2009) issued work permits for up to one year at a time, which could be renewed up to four times, but then expected foreign workers to leave its territory for at least one year before reapplying. In response, the Committee observed that the 'burdensome and complex' nature of these procedures risked encouraging irregular migration, and recommended that

107 Azerbaijan, 19 May 2009, paras 44-5.

108 General Comment No. 1, para. 52.

109 Senegal, 10 December 2010, para. 23.

110 Mexico, 20 December 2006, para. 34; Ecuador, 5 December 2007, para. 38; Ecuador, 15 December 2010, para. 28.

111 Ecuador, 15 December 2010, paras 6, 33 and 34

112 Bolivia, 29 April 2008, para. 32. 


\section{(C) Copyrighted Material}

the state 'consider reviewing the existing restrictions on the renewal of work permits'. ${ }^{113}$ On that occasion, its observations were based solely on the duty to implement the Convention (Articles 73 and 84), without reference to any substantive obligation. The Committee was more specific in General Comment No. 1 (2010) on migrant domestic workers, when it based a similar recommendation on Article 68 of the Convention:

With a view to preventing irregular migration as well as smuggling and human trafficking, States parties should ensure that migrant domestic workers have access to regular channels for migration based on actual demand (Article 68). ${ }^{114}$

Here too, the Committee treated Article 68 as implying a duty to design policy pre-emptively, so as to minimize irregular employment.

A second reason for the Committee's interest in legal migration policy is discrimination against a particular nationality. Relying upon the general principle of non-discrimination in Article 7 of the Convention, the Committee expressed its concern at Ecuador's (2007 and 2010) requirement that Colombian nationals produce an official certificate to show that they do not have a criminal record. ${ }^{115}$ In its view, this exclusive requirement risked contributing to the 'stigmatization and stereotyping' of Colombian nationals. ${ }^{116}$ Discrimination against particular nationalities within immigration policy appears therefore to be inherently suspect under Article 7.

Thirdly, the Committee has commented on provision for family reunification. The background is the uncertain obligation upon states in Article 44(2) (referred to in section 1) to 'take measures that they deem appropriate ... to facilitate' the reunification of migrant workers with spouses, persons in 'a relationship that, according to applicable law, produces effects equivalent to marriage', and minor dependent unmarried children. Given the lack of specificity within this provision, it is significant that the Committee expressed its concern that Algeria's (2010) regulations on family reunification for migrant workers applied to spouses alone, and called upon it to bring its policy into line with Article $44 .{ }^{117}$ The implication appears to be that a state must make some provision for the family members referred to in that Article.

\section{Conclusion}

This chapter has offered a broadly optimistic analysis of the Migrant Workers Convention as a source of standards for international migration. It started by arguing that criticisms of the Convention have for the most part been misplaced. The claim that the Convention unnecessarily duplicates provisions of other international human rights treaties underestimates the ways in

113 Azerbaijan, 19 May 2009, paras 14-15.

114 General Comment No. 1, para. 51.

115 Ecuador, 5 December 2007, paras 19-20, and 15 December 2010, paras 25-6.

116 Ecuador maintained its policy, arguing that it was necessary for reasons of public safety and public order: see 'Ecuador: Written Replies', 20 September 2010, para. 86.

117 Algeria, 19 May 2010, paras 32-3. The Committee also referred to Article 4, which sets out a definition of family member for the purpose of the Convention as a whole. 
which the Convention is a coherent instrument for the protection of migrants as a category. Similarly, the claim that the Convention gives insufficient protection to irregular migrants is at odds with the extensive protection it confers on that group, and reflects an over-interpretation of its provisions concerning immigration policy and control.

The chapter then showed how the potential of the Convention has been revealed in practice. The Convention is directly relevant to the circumstances of the states that have ratified it, as they all have experience as countries of origin of emigrants, while many have experience of immigration as transit and/or as destination locations. That argument was supported by a review of the work of the Committee on Migrant Workers to date. ${ }^{118}$ In the first place, the Committee has served as a mechanism for calling attention to clear failures of implementation by the states that have ratified - e.g., in relation to representation of emigrant nationals, the denial of trade union rights to foreign nationals, or the exclusion of irregular migrants from social protection. Beyond that, the Committee has shown a certain creativity in interpreting the Convention in the face of current issues in the field of international migration. One example is its advancement of the proposition that the Convention requires that migrant domestic workers should be protected by labour law. Other examples have concerned policy relating to irregular migration, where the Committee has rejected criminal penalties for breaches of immigration law and for irregular exit, promoted regularization, and proposed that the duty to prevent irregular migration and employment may require adjustments to legal migration policy.

The overall conclusion to be drawn is that the Convention has a clear role in relation to the states that have ratified it, especially where those states engage with the Committee on Migrant Workers. Going forward, two initiatives appear desirable, in order to clarify the Convention's potential value. Firstly, research into the Convention ought to focus on the states that have ratified it, rather than - as hitherto - upon those that have not. Secondly, the Committee's approach to the protection of migrants would be more authoritative if it were more clearly and consistently linked to particular provisions of the Convention. Each of these steps may be thought critical in enhancing support for the Convention as a source of norms in the contemporary migration context.

\section{References}

Battistella, Graziano, 'Migration and Human Rights: The Uneasy but Essential Relationship' in Paul de Guchteneire, Antoine Pécoud and Ryszard Cholewinski (eds), Migration and Human Rights: The United Nations Convention on Migrant Workers' Rights (Cambridge University Press, Cambridge, 2009) 47-69.

Böhning, Roger, 'The ILO and the New UN Convention on Migrant Workers: The Past and Future' (1991) 25 International Migration Review 698-709.

118 Slinckx has offered a similar assessment of the Committee's potential - 'the CMW ... offers an expert understanding of the specificities of the situation of migrants': Slinckx, 'Migrants' Rights in UN Human Rights Conventions', 149. 
Böhning, Roger, 'The Protection of Migrant Workers and International Labour Standards' (1988) 26 International Migration 133-46.

Bosniak, Linda, 'Human Rights, State Sovereignty, and the Protection of Undocumented Migrants under the International Convention for the Protection of the Rights of All Migrant Workers and Members of Their Families' (1991) 25 International Migration Review 737-70.

Chetail, Vincent, 'Review of Migration and Human Rights: The United Nations Convention on Migrant Workers' (2010) 22 International Journal of Refugee Law 677-82.

Chetail, Vincent and Gilles Giacca, 'Who Cares? The Right to Health of Migrants' in Andrew Clapham and Mary Robinson (eds), Realising the Right to Health (Rueffer, Zurich, 2009) 224-34.

Cholewinski, Ryszard, Migrant Workers in International Human Rights Law: Their Protection in Countries of Employment (Oxford University Press, Oxford, 1997).

Colyer, Michael and Hein de Haas, 'Developing Dynamic Categorisations of Transit Migration' (2011) 17 Population, Space and Place 468-81.

De Guchteneire, Paul and Antoine Pécoud, 'Introduction: The UN Convention on Migrant Workers' Rights' in Paul de Guchteneire, Antoine Pécoud and Ryszard Cholewinski (eds), Migration and Human Rights: The United Nations Convention on Migrant Workers' Rights (Cambridge University Press, Cambridge, 2009) 1-44.

Díaz, Gabriela and Gretchen Kuhner, 'Mexico's Role in Promoting and Implementing the ICRMW' in Paul de Guchteneire, Antoine Pécoud and Ryszard Cholewinski (eds), Migration and Human Rights: The United Nations Convention on Migrant Workers' Rights (Cambridge University Press, Cambridge, 2009) 219-46.

Edelenbos, Carla, 'Committee on Migrant Workers and Implementation of the ICRMW' in Paul de Guchteneire, Antoine Pécoud and Ryszard Cholewinski (eds), Migration and Human Rights: The United Nations Convention on Migrant Workers' Rights (Cambridge University Press, Cambridge, 2009) 100-121.

Escobar Latapí, Agustín, The Future of Migration Policies in the Americas (IOM, Geneva, 2010).

Hune, Shirley and Jan Niessen, 'Ratifying the UN Migrant Workers Convention: Current Difficulties and Prospects' (1994) 12 Netherlands Quarterly of Human Rights 130-41.

Lönnroth, Juhani, 'The International Convention on the Rights of All Migrant Workers and Members of Their Families in the Context of International Migration Policies: An Analysis of Ten Years of Negotiation' (1991) 25 International Migration Review 710-36.

Nafziger, James and Barry Bartel, 'The Migration Workers Convention: Its Place in Human Rights Law' (1991) 25 International Migration Review 771-99.

Slinckx, Isabelle, 'Migrants' Rights in UN Human Rights Conventions' in Paul de Guchteneire, Antoine Pécoud and Ryszard Cholewinski (eds), Migration and Human Rights: The United Nations Convention on Migrant Workers' Rights (Cambridge University Press, Cambridge, 2009) 122-49. 